\title{
Time course of the changes in uterine vascular permeability associated with the development of the decidual cell reaction in ovariectomized steroid-treated rats
}

\author{
S. R. Milligan and Florence M. Mirembe* \\ Department of Physiology, King's College, Strand, London WC2R 2LS, U.K.
}

\begin{abstract}
Summary. Uterine vascular permeability and tissue blood volume during the development of the oil-induced decidual cell reaction (DCR) in ovariectomized steroidtreated rats were assessed by measuring the extravascular accumulation of ${ }^{125} \mathrm{I}$-labelled human serum albumin and the tissue content of ${ }^{51} \mathrm{Cr}$-labelled red cells $30 \mathrm{~min}$ after intravenous administration. Within $15 \mathrm{~min}$ of oil instillation into one uterine horn, the vascular permeability of the horn was significantly elevated. Permeability rose to a sharp peak (10 times control levels) $9 \mathrm{~h}$ after oil instillation, but dropped to 5 times control values by $12 \mathrm{~h}$ and continued a steady decline over the next 7 days. Although a marked increase in uterine weight was associated with the development of the DCR, there was no significant change in blood volume/g tissue until 4 days after oil instillation.
\end{abstract}

\section{Introduction}

One of the earliest signs of implantation of the blastocyst is a localized increase in endometrial vascular permeability. This permeability change may also be induced by other deciduogenic stimuli and is believed to be essential for the decidual cell reaction (Psychoyos, 1973). The increase in permeability can be readily visualized a few minutes after the injection of dyes such as Evans Blue and Pontamine Sky Blue (Psychoyos, 1973) and this has been widely used for the identification of early implantation sites. Although the changes in vascular permeability have been widely studied in relation to the possible causal factors (Brandon, 1980; Kennedy, 1980), there is surprisingly little information on the time course or magnitude of the response. In rats, an increase in vascular permeability has been detected in suitably sensitized uteri $2 \mathrm{~h}$ after the intraluminal injection of phosphate-buffered saline containing $0 \cdot 1 \%$ gelatin (PBS-G) (Kennedy, 1979), $3 \mathrm{~h}$ after scratching the endometrium (Psychoyos, 1961), $4 \mathrm{~h}$ after the intraluminal instillation of oil (Lundkvist, Ljungkvist \& Nilsson, 1977) and $8 \mathrm{~h}$ after the transfer of blastocysts (Lundkvist \& Nilsson, 1982). The duration of the increased vascular permeability is uncertain, but Kennedy (1979) observed that it had declined to control levels within $18 \mathrm{~h}$ of the instillation of PBS-G. Changes in uterine blood volume may also accompany the decidual cell reaction: Psychoyos (1961) and Bitton, Vassent \& Psychoyos (1965) noted a significant increase in total blood volume $6 \mathrm{~h}$ after traumatization. The present study was undertaken to provide more detailed information on the time course and magnitude of the changes in vascular permeability and blood volume associated with the decidual

* Present address: Department of Obstetrics \& Gynaecology, Mulago Hospital, P.O. Box 7051, Kampala, Uganda. 
cell response induced by oil in ovariectomized steroid-treated rats. These details are important in trying to understand the morphological and biochemical changes accompanying decidualization (Finn, 1977) and the role of such factors as prostaglandins (Kennedy, 1980; Kennedy \& Lukash, 1982) in mediating the vascular and decidual responses.

\section{Materials and Methods}

Animals. Mature female Wistar rats (Charles River (U.K.) Ltd, Margate, Kent) weighing 180$250 \mathrm{~g}$ were kept under conditions of controlled lighting $(12 \mathrm{~h} \mathrm{light} /$ day $)$ and temperature $\left(21 \pm 1^{\circ} \mathrm{C}\right)$ with free access to food (41B, Oxoid) and water. Females were ovariectomized under ether anaesthesia 2 weeks before use. Injections of oestradiol-17 $\beta$ and progesterone (Sigma London Chemical Co. Ltd) were given subcutaneously in $0.2 \mathrm{ml}$ arachis oil (British Drug Houses Ltd). The first day of steroid treatment was designated Day 1. Decidualization was induced in rats anaesthetized with ether by the intraluminal injection of $50 \mu 1$ arachis oil through a 25 -gauge needle at the anterior tip of the uterine horn. The contralateral control uterine horn was subject to the same handling procedure but was not injected.

Ovariectomized females were primed with $500 \mathrm{ng}$ oestradiol-17 7 on Days 1 and 2 . From Day 5 , females were treated daily with $3 \mathrm{mg}$ progesterone at $11: 00 \mathrm{~h}$. On Day 7, $50 \mathrm{ng}$ oestradiol-17 $\beta$ were given at 16:00 h. Intrauterine injection of oil into one uterine horn and manipulation of the control horn were performed between 10:00 and 12:00 h on Day 8. From Day 8 onwards, females received $200 \mathrm{ng}$ oestradiol-17 $\beta$ in addition to progesterone.

Estimation of vascular permeability and blood volume. A quantitative estimate of the permeability to large molecules was obtained from the leakage of radiolabelled albumin from the circulation. The blood volume of tissues was determined from the content of radiolabelled red cells. Isotopes were obtained from Amersham International Ltd, U.K.

Using ether anaesthesia, the external jugular was exposed and $0.5 \mathrm{ml} \mathrm{blood} \mathrm{was} \mathrm{removed} \mathrm{before}$ injecting $2.5 \mu \mathrm{Ci}^{125} \mathrm{I}$-labelled human serum albumin (HSA) in a volume of $0.1 \mathrm{ml} 0.154 \mathrm{M}-\mathrm{NaCl}$ and $0.5 \mathrm{ml}{ }^{51} \mathrm{Cr}$-labelled rat red blood cells. The red cells were labelled according to the method of Bitton et al. (1965) and $\sim 200 \mu \mathrm{l}$ red cells labelled with $25 \mu \mathrm{Ci}{ }^{51} \mathrm{Cr}$ were injected into each rat. The animals were allowed to recover but weré killed 30 min later by cervical dislocation under ether anaesthesia. A blood sample $(0.5 \mathrm{ml})$ was taken from the contralateral jugular immediately before death and a portion of this was centrifuged to obtain a plasma sample $(100 \mu \mathrm{l})$. The two uterine horns and small pieces of diaphragm (as a control tissue) were removed, gently rinsed (in $0.154 \mathrm{M}$ $\mathrm{NaCl}$ ) and blotted before weighing. Radioactivity in tissue, blood and plasma samples was determined using a Nuclear Enterprises automatic gamma counter, with appropriate correction for cross-over between isotopes. All counts were corrected to counts $/ \mathrm{mg}$ tissue. Tissue blood volumes were determined from the relative content of ${ }^{51} \mathrm{Cr}$ in the blood and tissue samples on the assumption that tissue and systemic haematocrits were identical. Extravascular ${ }^{125}$ I-labelled HSA accumulation was determined on the assumption that all ${ }^{125} \mathrm{I}$ was protein bound, using the expression:

Whole tissue ${ }^{125}$ I c.p.m./mg - (blood ${ }^{125} \mathrm{I}$ c.p.m. $/ \mu \mathrm{l} \times \mu \mathrm{l}$ blood $/ \mathrm{mg}$ tissue)

and expressed as:

$$
\frac{\text { extravascular }{ }^{125} I \text { c.p.m./g tissue }}{{ }^{125} \mathrm{I} \text { c.p.m./ } / \mu \text { l plasma }}
$$

This value ( $\mu \mathrm{l} / \mathrm{g}$ tissue) is the "apparent plasma equivalent extravascular albumin volume" (Bill, 1964, 1968).

To confirm that the tissue content of ${ }^{125} \mathrm{I}$-labelled HSA $30 \mathrm{~min}$ after intravenous administration was a reflection of vascular permeability and was not limited by the extravascular space available, a 
comparison was made between females (instilled with oil $6 \mathrm{~h}$ previously) killed $30 \mathrm{~min}$ and $1.5 \mathrm{~h}$ after injection of ${ }^{125}$ I-labelled HSA.

Vascular permeability and tissue blood volume were determined in females killed $15 \mathrm{~min}$, 30 min, $1 \cdot 5,3,6,9,12$ or $18 \mathrm{~h}$, and $1,2,3,4,5$ or 7 days after intrauterine oil instillation and in an additional group of females immediately before the normal time of oil instillation. In females killed $15 \mathrm{~min}$ after oil instillation, the circulation time for the ${ }^{125} \mathrm{I}$-labelled HSA and ${ }^{51} \mathrm{Cr}$-labelled red cells was only $15 \mathrm{~min}$.

Analysis of results. Results were analysed using Student's paired and unpaired $t$ tests, and analysis of variance, as appropriate.

\section{Results}

The extravascular albumin volume measured $30 \mathrm{~min}$ after injection of ${ }^{125}$ I-labelled HSA and $6 \mathrm{~h}$ after oil instillation was $23.7 \pm 3.0 \mu \mathrm{l} / \mathrm{g}$ (mean \pm s.e.m.) in the control uterine horn and $171 \pm$ $32 \mu \mathrm{l} / \mathrm{g}(n=6)$ in the instilled horn. When the determination of this volume was made $1.5 \mathrm{~h}$ after HSA injection, the values were significantly higher at $50 \cdot 3 \pm 4 \cdot 4$ and $335 \pm 52 \mu 1 / \mathrm{g}$ respectively $(n$ $=4$ ). This suggests that the extravascular albumin volume determined after $30 \mathrm{~min}$ is not limited by the extravascular space available and can be used as a reflection of vascular permeability.

Uterine weights and blood volumes at various times after oil instillation are summarized in Table 1. A significant increase in the weight of the instilled horn over the control horn was apparent $6 \mathrm{~h}$ after instillation and the difference became more pronounced at later times with the development of massive decidual cell reactions in the instilled horns. The total blood volume of the instilled horn increased as the uterine weight rose, but no significant changes in blood volume/g tissue occurred over the first 3 days $(F=2 \cdot 13$, d.f. $=8,35, P>0.05)$. No changes in tissue blood volume were apparent for the diaphragm $(\mathrm{F}=1.47$, d.f. $=12,48, P>0.05)$ or control horn $(\mathrm{F}=$ $1 \cdot 24$, d.f. $=12,50, P>0 \cdot 05$ ).

No significant changes were observed in the diaphragm extravascular albumin volume at any time $(\mathrm{F}=1.71$, d.f. $=12,48, P>0.05)$ (Text-fig. 1$)$. Although small variations in the control horn extravascular albumin volume were apparent $(\mathrm{F}=2.42$, d.f. $=12,50, P<0.05)$, these were minor in comparison with the changes in the instilled horn (Text-fig. 1). A significant elevation in the extracellular albumin volume of the instilled horn was apparent within $15 \mathrm{~min}$ of oil injection (control horn $=16.7 \pm 0.91 \mu \mathrm{l} / \mathrm{g}$; instilled horn $=28.9 \pm 0.46 \mu \mathrm{l} / \mathrm{g} ; t=3.75, P<0.02$ ), and was significantly higher in the instilled horn than the control horn at all other times. The extravascular accumulation of ${ }^{125}$ I-labelled HSA showed a sharp peak $9 \mathrm{~h}$ after instillation with a mean level about 10 times that of the control horn. Within $12 \mathrm{~h}$ of oil instillation, the mean extravascular albumin volume had fallen to about 5 times control levels and continued to show a slow decline over the next 7 days. Only small differences between the control and instilled horns were apparent after 5 and 7 days, but paired $t$ tests revealed that these were still statistically significant $(t=4 \cdot 1, P<0.05$, and $t=5.07, P<0.02$, respectively).

\section{Discussion}

Although the extracellular accumulation of visible markers such as pontamine blue has been very useful in identifying sites of early implantation and decidualization (Psychoyos, 1960, 1973; Lundkvist \& Nilsson, 1982), it is probably less sensitive than the determination of extravascular protein-bound ${ }^{125} \mathrm{I}$. Whenever the extravascular accumulation of ${ }^{125} \mathrm{I}$ has been used to investigate the events accompanying decidualization, an increase in vascular permeability has been found at the very earliest times examined ( $3 \mathrm{~h}$ : Psychoyos, 1961; $2 \mathrm{~h}$ : Kennedy, 1979). In contrast, pontamine blue sites may not become apparent until about $4 \mathrm{~h}$ after the application of an artificial 
Table 1. Uterine horn weights and tissue blood volumes in ovariectomized steroidtreated rats at various times after the instillation of oil into one uterine horn

\begin{tabular}{|c|c|c|c|c|c|c|}
\hline \multirow{2}{*}{$\begin{array}{l}\text { Time after } \\
\text { instillation }\end{array}$} & \multirow{2}{*}{$\begin{array}{l}\text { No. of } \\
\text { rats }\end{array}$} & \multicolumn{2}{|c|}{ Uterine weight (mg) } & \multicolumn{3}{|c|}{ Blood volume $(\mu 1 / g)$} \\
\hline & & Control & Instilled & Control & Instilled & Diaphragm \\
\hline $0 \mathrm{~h}$ & 5 & $\begin{array}{r}78 \cdot 6 \\
\pm 3 \cdot 1\end{array}$ & $\begin{array}{r}77 \cdot 1 \\
\pm 4 \cdot 2\end{array}$ & $\begin{array}{r}11.0 \\
\pm 0.9\end{array}$ & $\begin{array}{r}10.5 \\
\pm 0.8\end{array}$ & $\begin{array}{r}23 \cdot 1 \\
\pm 1 \cdot 1\end{array}$ \\
\hline $0.5 \mathrm{~h}$ & 5 & $\begin{array}{r}88.7 \\
\pm 6 \cdot 3\end{array}$ & $\begin{array}{r}72.0 \\
\pm 5.8\end{array}$ & $\begin{array}{r}9.2 \\
\pm 0.9\end{array}$ & $\begin{array}{r}8.3 \\
+1.4\end{array}$ & $\begin{array}{r}21.2 \\
\pm 1.6\end{array}$ \\
\hline $1.5 \mathrm{~h}$ & 4 & $\begin{array}{r}86 \cdot 0 \\
\pm 7 \cdot 4\end{array}$ & $\begin{array}{r}71.8 \\
\pm 7 \cdot 1\end{array}$ & $\begin{array}{r}12 \cdot 1 \\
\pm 1 \cdot 4\end{array}$ & $\begin{array}{r}13.4 \\
\pm 1.1\end{array}$ & $\begin{array}{r}20 \cdot 6 \\
\pm 1 \cdot 0\end{array}$ \\
\hline $3 \mathrm{~h}$ & 5 & $\begin{array}{r}72 \cdot 4 \\
\pm 6 \cdot 3\end{array}$ & $\begin{array}{r}63.5 \\
\pm 6.8\end{array}$ & $\begin{array}{r}9.0 \\
+0.8\end{array}$ & $\begin{array}{r}10 \cdot 3 \\
\pm 1 \cdot 1\end{array}$ & $\begin{array}{r}20.6 \\
\pm 0.9\end{array}$ \\
\hline $6 \mathrm{~h}$ & 6 & $\begin{array}{r}74 \cdot 2 \\
\pm 5 \cdot 7\end{array}$ & $\begin{array}{r}+96.0 \\
\pm 8.7\end{array}$ & $\begin{array}{r}10.5 \\
\pm 0.9\end{array}$ & $\begin{array}{r}11.0 \\
\pm 0.7\end{array}$ & $\begin{array}{r}21.5 \\
\pm 1.2\end{array}$ \\
\hline $9 \mathrm{~h}$ & 5 & $\begin{array}{r}80.2 \\
\pm 5.5\end{array}$ & $\begin{array}{l}\dagger 115.4 \\
\pm 15.5\end{array}$ & $\begin{array}{r}9.0 \\
+1.4\end{array}$ & $\begin{array}{r}10.4 \\
\pm 1.5\end{array}$ & $\begin{array}{r}19.0 \\
\pm 1.7\end{array}$ \\
\hline $12 \mathrm{~h}$ & 5 & $\begin{array}{r}73.4 \\
\pm 7.5\end{array}$ & $\begin{array}{l}\dagger 135.6 \\
\pm 13.5\end{array}$ & $\begin{array}{r}10.5 \\
\pm 2.2\end{array}$ & $\begin{array}{r}7.8 \\
\pm 1.4\end{array}$ & $\begin{array}{r}23.0 \\
\pm 1.6\end{array}$ \\
\hline $18 \mathrm{~h}$ & 6 & $\begin{array}{r}81 \cdot 2 \\
\pm 5 \cdot 1\end{array}$ & $\begin{array}{l}+157.7 \\
\pm 10.5\end{array}$ & $\begin{array}{r}9.9 \\
+0.9\end{array}$ & $\begin{array}{r}11 \cdot 0 \\
\pm 1 \cdot 3\end{array}$ & $\begin{array}{r}24.7 \\
\pm 0.9\end{array}$ \\
\hline 1 day & 4 & $\begin{array}{r}72.5 \\
\pm 2.5\end{array}$ & $\begin{array}{l}+167.5 \\
\pm 10.4\end{array}$ & $\begin{array}{r}12.4 \\
\pm 1.5\end{array}$ & $\begin{array}{r}12.1 \\
\pm 1.7\end{array}$ & $\begin{array}{r}25 \cdot 1 \\
\pm 4.4\end{array}$ \\
\hline 2 days & 5 & $\begin{array}{r}81 \cdot 2 \\
\pm 4.6\end{array}$ & $\begin{array}{r}+227 \cdot 4 \\
\pm 43 \cdot 2\end{array}$ & $\begin{array}{r}10 \cdot 2 \\
\pm 1 \cdot 3\end{array}$ & $\begin{array}{r}7.7 \\
\pm 0.3\end{array}$ & $\begin{array}{r}21.2 \\
\pm 0.8\end{array}$ \\
\hline 3 days & 5 & $\begin{array}{r}53.8 \\
\pm 8.0\end{array}$ & $\begin{array}{l}\dagger 339 \cdot 2 \\
\pm 34 \cdot 6\end{array}$ & $\begin{array}{r}8.3 \\
\pm 0.6\end{array}$ & $\begin{array}{r}12.9 \\
\pm 1.6\end{array}$ & $\begin{array}{r}27.5 \\
\pm 1.5\end{array}$ \\
\hline 4 days & 4 & $\begin{array}{c}82 \\
\pm 7 \cdot 6\end{array}$ & $\begin{array}{l}+850 \cdot 5 \\
\pm 135\end{array}$ & $\begin{array}{r}10 \cdot 8 \\
\pm 2.7\end{array}$ & $\begin{array}{l}* 16 \cdot 3 \\
\pm 3 \cdot 2\end{array}$ & $\begin{array}{r}19.6 \\
\pm 1.9\end{array}$ \\
\hline 5 days & 5 & $\begin{array}{r}119.4 \\
\pm 5.9\end{array}$ & $\begin{array}{l}+1169 \\
\pm 64 \cdot 6\end{array}$ & $\begin{array}{r}9.6 \\
\pm 0.8\end{array}$ & $\begin{array}{l}* 16 \cdot 2 \\
\pm 2 \cdot 3\end{array}$ & $\begin{array}{r}20.4 \\
\pm 1.4\end{array}$ \\
\hline 7 days & 4 & $\begin{array}{l}116 \\
\pm 1.7\end{array}$ & $\begin{array}{l}+1449 \\
\pm 88 \cdot 6\end{array}$ & $\begin{array}{r}13.8 \\
\pm 1.1\end{array}$ & $\begin{array}{l}* 32.6 \\
\pm 6.4\end{array}$ & $\begin{array}{r}23.5 \\
\pm 2.6\end{array}$ \\
\hline
\end{tabular}

Values are means \pm s.e.m.

Values significantly different from control horn: ${ }^{*} P<0.05, \dagger P<0.01$.

stimulus (Lundkvist et al., 1977). In the present study, a rise in vascular permeability was apparent within $15 \mathrm{~min}$ of the instillation of oil to suitably sensitized rat uteri, considerably earlier than previously reported. Marked quantitative changes in the vascular response occurred over the next $24 \mathrm{~h}$, with a sharp peak in the response at $9 \mathrm{~h}$. Vascular permeability did not decline to control levels within $18 \mathrm{~h}$ as described by Kennedy (1979), but a number of differences in experimental design may account for this: in the study by Kennedy (1979) (a) hormone-primed immature females were used; (b) the stimulus for decidualization was PBS-G and not oil : oil may remain in the uterus for at least $24 \mathrm{~h}$ and may provide a more traumatic stimulus (Lundkvist \& Nilsson, 1982); and (c) no marker for vascular space was used.

The causes of the changes in vascular permeability are still unknown, although prostaglandins (PGs) have been strongly implicated (Kennedy, 1980). Kennedy \& Lukash (1982) observed a 7-fold increase in uterine PGE concentrations and a 17 -fold increase in PGF concentrations within 5 min of oil instillation and such changes may be important in mediating the early responses. The role of PGs at later stages is uncertain: although indomethacin may reduce the decidual response even when given up to $48 \mathrm{~h}$ after the oil stimulus, the uterine concentrations of PGE and PGF normally decline to baseline levels within 6 and 24 h respectively (Kennedy \& Lukash, 1982). 


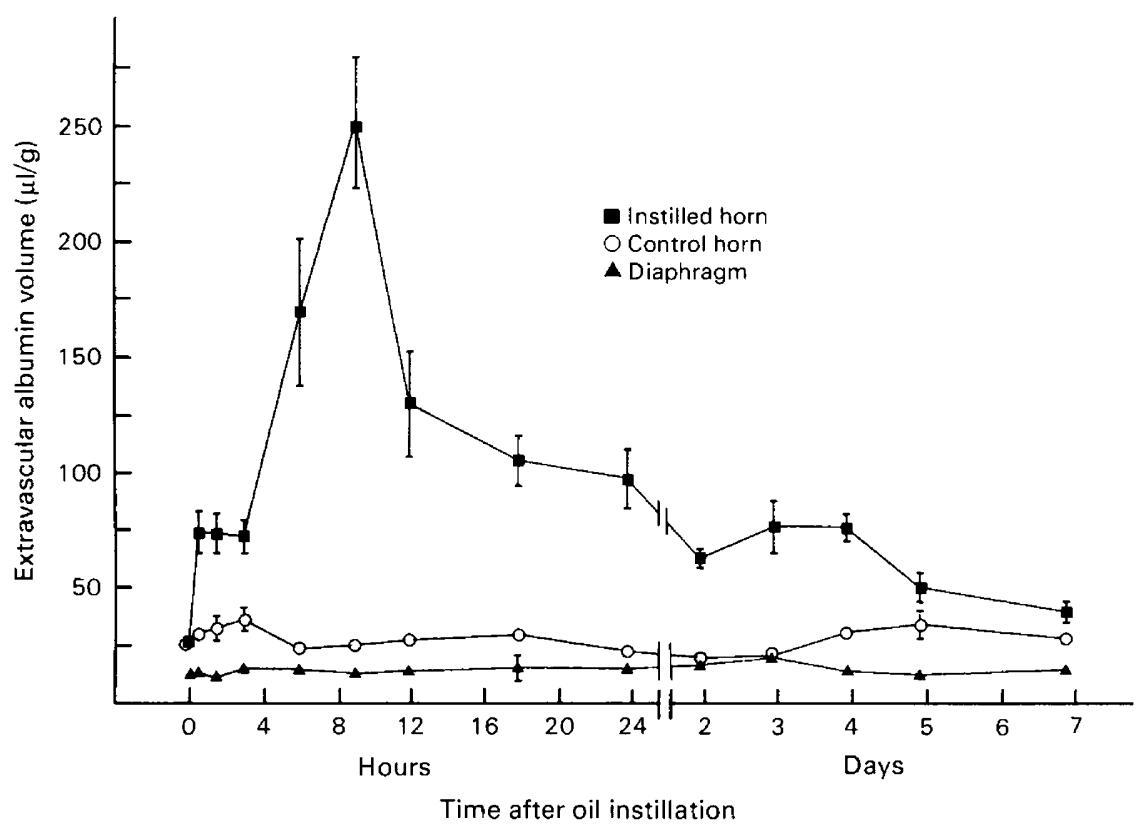

Text-fig. 1. Changes (mean \pm s.e.m.) in the apparent plasma equivalent extravascular albumin volume after the instillation of $50 \mu \mathrm{l}$ arachis oil into one uterine horn of ovariectomized steroid-treated rats. The number of observations $(\geqslant 4)$ at each point is as in Table 1.

The increase in uterine weight in the instilled horn due to the development of the decidual reaction was accompanied by a proportionate increase in total blood volume, with the result that blood volume/g tissue showed little change. Oedema precedes decidual transformation of the stromal cells (Finn, 1977) and is presumably the result of the early increase in vascular permeability. Although increased vascular permeability always precedes decidualization (Psychoyos, 1973; Kennedy \& Lukash, 1982), its significance in relation to the decidual process is unknown. Sorger \& Soderwall (1981) suggested that the oedema may provide a signal for the growth of the uterine tissues. Signs of incipient stromal cell differentiation are apparent $8 \mathrm{~h}$ after oil instillation (Lundkvist \& Nilsson, 1982) and the greatly increased vascular permeability around this time may facilitate the access of a variety of plasma constituents (including proteins and protein-bound steroids) to the stromal cells. These may be important in the induction and maintenance of decidual transformation.

We thank Simon Devine for technical assistance; The Wellcome Trust for funding this research; and the British Council for support of F.M.

\section{References}

Bill, A. (1964) The albumin exchange in the rabbit eye. Acta physiol. scand. 60, 18-29.

Bill, A. (1968) Capillary permeability to and extravascular dynamics of myoglobin, albumin and gammaglobulin in the uvea. Acta physiol. scand. 73, 204-219.

Bitton, V., Vassent, G. \& Psychoyos, A. (1965) Résponse vasculaire de l'utérus au traumatisme, au cours de la pseudogestation chez la ratte. C. r. hebd. Séanc. Acad. Sci., Paris D 261, 3474-3477.
Brandon, J.M. (1980) Some recent work on the role of histamine in ovum implantation. In Progress in Reproductive Biology, Vol. 7, pp. 244-252. Eds F. Leroy, C. A. Finn, A. Psychoyos \& P. O. Hubinont. Karger, Basel.

Finn, C.A. (1977) The implantation reaction. In Biology of the Uterus, pp. 245-308. Ed. R. M. Wynn. Plenum Press, New York.

Kennedy, T.G. (1979) Prostaglandins and increased Downloaded from Bioscientifica.com at 04/26/2023 11:50:33AM 
endometrial vascular permeability resulting from the application of an artificial stimulus to the uterus of the rat sensitised for the decidual cell reaction. Biol. Reprod. 20, 560-566.

Kennedy, T.G. (1980) Prostaglandins and the endometrial vascular permeability changes preceding blastocyst implantation and decidualisation. In Progress in Reproductive Biology, Vol. 7, pp. 234-243. Eds F. Leroy, C. A. Finn, A. Psychoyos \& P. O. Hubinont. Karger, Basel.

Kennedy, T.G. \& Lukash, L.A. (1982) Induction of decidualisation in rats by the intrauterine infusion of prostaglandins. Biol. Reprod. 27, 253-260.

Lundkvist, O. \& Nilsson, B.O. (1982) Endometrial ultrastructure in the early uterine response to blastocysts and artificial deciduogenic stimuli in rats. Cell Tiss. Res. 225, 355-364.
Lundkvist, O., Ljungkvist, I. \& Nilsson, O. (1977) Early effects of oil on rat uterine epithelium sensitized for decidual induction. J. Reprod. Fert. 52, 507-509.

Psychoyos, A. (1960) La réaction déciduale est précedée de modifications précoces de la permeabilité capillaire de l'utérus. C. r. Séanc. Soc. Biol. 154, 1384 1387.

Psychoyos, A. (1961) Permeabilité capillaire et décidualisation utérine. C. r. hebd. Séanc. Acad. Sci. Paris D 252, 1515-1517.

Psychoyos, A. (1973) Endocrine control of egg implantation. In Handbook of Physiology, Section 7, Vol. II, Part 2, pp. 187-215. Eds R. O. Greep, E. G. Astwood \& S. R. Geiger. Am. Physiol. Soc., Washington, D.C.

Sorger, T. \& Soderwall, A. (1981) The aging uterus and the role of oedema in endometrial function. Biol. Reprod. 24, 1135-1144.

Received 16 February 1982 